\title{
The quest for a true One Health perspective of brucellosis
}

J. Godfroid ${ }^{(1,2)^{*}}$, X. DeBolle ${ }^{(3)}$, R.M. Roop $2^{\text {nd }}(4)$, D. O'Callaghan ${ }^{(5,6)}$, R.M. Tsolis ${ }^{(7)}$, C. Baldwin ${ }^{(8)}$, R.L. Santos ${ }^{(9)}$, J. McGiven ${ }^{(10)}$, S. Olsen ${ }^{(11)}$, I.H. Nymo ${ }^{(1)}$, A. Larsen ${ }^{(1)}$, S. Al Dahouk ${ }^{(12)}$ \& J.J. Letesson ${ }^{(3)}$

(1) University of Tromsø, Arctic University of Norway, Department of Arctic and Marine Biology, 9010 Tromsø, Norway

(2) Department of Veterinary Tropical Diseases, Faculty of Veterinary Science, University of Pretoria, 0110 Onderstepoort, South Africa

(3) University of Namur, Department of Biology, URBM, 5000 Namur, Belgium

(4) East Carolina University, Department of Microbiology and Immunology, Brody School of Medicine, Greenville, NC 27858, United States of America

(5) Institut national de la santé et de la recherche médicale (INSERM) U1047, UFR Médecine, 186 chemin du Carreau de Lanes, CS 83021, 30908 Nîmes Cedex 2, France

(6) Université Montpellier 1, UFR de Médecine, 186 chemin du Carreau de Lanes, CS 83021, 30908 Nîmes Cedex 2, France

(7) University of California, Department of Medical Microbiology and Immunology, School of Medicine, Davis, CA 95616, United States of America

(8) University of Massachusetts, Department of Veterinary and Animal Sciences, Amherst, MA 01003, United States of America

(9) Universidade Federal de Minas Gerais, Departamento de Clínica e Cirurgia Veterinárias, Escola de Veterinaria, Belo Horizonte, Minas Gerais, Brazil

(10) Animal Health Veterinary Laboratories Agency (World Organisation for Animal Health Reference Laboratory for Brucellosis, World Health Organization/Food and Agriculture Organization of the United Nations Collaborating Centre for Brucellosis), Woodham Lane, Addlestone, Weybridge, Surrey, KT15 2NB, United Kingdom

(11) Bacterial Diseases of Livestock Research Unit, National Animal Disease Center, Agricultural Research Service, United States Department of Agriculture, Ames, IA 50010, United States of America

(12) Federal Institute for Risk Assessment, Diedersdorfer Weg 1, D-12277, Berlin, Germany

*Corresponding author: Jacques.godfroid@uit.no

\section{Summary}

One Health is an interdisciplinary collaboration that aims at mitigating risks to human health arising from microorganisms present in non-human animal species, which have the potential to be transmitted and cause disease in humans. Different degrees of scientific collaboration and sectoral integration are needed for different types of zoonotic diseases, depending on the health and associated economic gains that can be expected from a One Health approach. Indeed, mitigating zoonotic risks related to emerging diseases with pandemic potential is different from mitigating risks related to endemic zoonotic diseases like brucellosis. Likewise, management of brucellosis at the wildlife-livestock interface in wildlife conservation areas is in essence different from mitigating transmission of a given Brucella species within its preferential host species, which in turn is different from mitigating the spillover of a given Brucella species to non-preferential host species, humans included. Brucellosis economic models often oversimplify and/or wrongly assess transmission between reservoir hosts and spillover hosts. Moreover, they may not properly value non-market outcomes, such as avoidance of human disease, consumer confidence and conservation biology issues. As a result, uncertainty is such that the economic predictions of these models can be questionable. Therefore, understanding the infection biology of Brucella species is a prerequisite. This paper reviews and highlights important features of the infection biology of Brucella species and the changing epidemiology of brucellosis that need to be integrated into a true One Health perspective of brucellosis.

\section{Keywords}

Brucella spp. - Brucellosis - Diagnostic - Epidemiology - Host specificity - Immunity Infection biology - One Health - Resistance - Zoonosis. 


\section{Introduction}

One Health is an interdisciplinary collaboration that aims at mitigating risks to human health arising from microorganisms (potentially pathogens) present in nonhuman animal species. Changes in the burden of human diseases, their spatial distribution, and types of pathogens of concern, have arisen largely due to changing human activities that are occurring as a result of increasing populations and economic development. Interaction of humans and livestock with wildlife exposes them to the risk of pathogen spillover. Livestock may become intermediate or amplifier hosts from which pathogens can spill over into humans or humans can be infected either directly from wildlife or via vectors (1). It has been estimated that $58 \%$ of human pathogens are zoonotic, and 13\% are emerging, of which $73 \%$ are zoonotic (2). Additionally, $26 \%$ of human pathogens infect both domestic and wild animals (3).

Such information helped the One Health concept to gain momentum, putting the emphasis on emerging zoonoses, particularly those viral emerging zoonoses with pandemic potential, such as Ebola, severe acute respiratory syndrome (SARS) and H1N1 influenza (4). Brucellosis, however, is a bacterial disease, usually enzootic, with, under certain epidemiological situations, an increasing prevalence in livestock and/or wildlife, leading to an increased incidence in humans at a local or regional level. We understand intuitively that the measures needed to mitigate the burden of zoonoses with pandemic potential are different from those needed to mitigate the risks from brucellosis, an infection whose hallmark is chronicity. Likewise, it seems obvious that the degree of cross-sector integration needed (e.g. between public health, veterinary public health and environment health) will vary too (5). In the case of an emerging zoonosis with pandemic potential, for example, collaboration between the animal and public health sectors is vital, because early detection in the animal reservoir is paramount in order to avoid transmission to humans. However, cooperative action between these two sectors is less urgent in cases of enzootic brucellosis, which does not spread quickly, and often displays a patchy distribution of high or low prevalence at both local and regional levels (6).

It is worth noting that, in some developed countries, brucellosis has been eradicated and has thus become exotic or alien. From an economic point of view, it is of the utmost importance to achieve and to keep 'brucellosisfree' status. Indeed, if this status is lost, national and international veterinary regulations impose restrictions on animal movements and trade, which can result in huge economic losses (7). In such situations, brucellosis is seen as an economic disease of livestock, and management is a matter for national Veterinary Services. Measures focus on recovering 'brucellosis-free' status and the disease is not viewed from a One Health perspective.
Regardless of the type of zoonosis, there is a common need to decipher and understand the infection biology of pathogens in order to be able to design and implement valid mitigation strategies. In 2013 the World Organisation for Animal Health (OIE) published an issue of the Scientific and Technical Review which looked at brucellosis from the One Health perspective (web.oie.int/boutique/). This paper will not summarise this information, but is rather aiming to highlight new research findings related to the infection biology of Brucella spp. and to the changing epidemiology of brucellosis, which are crucial for defining a true One Health perspective of brucellosis.

Brucellae are Gram-negative, facultative intracellular bacteria that can infect many mammalian species, including humans. Ten species are recognised within the genus Brucella:

- a group composed of the six 'classical' Brucella species, some of which include different biovars: Brucella abortus (biovars 1, 2, 3, 4, 5, 6, 7, 9), B. melitensis (biovars 1, 2,3 ), B. suis (biovars $1,2,3,4,5$ ), B. ovis, B. canis and B. neotomae

- a group represented by the 'new' recently described species: B. ceti and B. pinnipedialis, B. microti and B. inopinata.

Worldwide, the main pathogenic species for livestock are:

- B. abortus (all biovars), responsible for bovine brucellosis

- B. melitensis (all biovars), the main aetiological agent of brucellosis in both small ruminants and humans

- B. suis (biovars 1, 2 and 3), responsible for swine brucellosis

- B. ovis, causing brucellosis in sheep.

The capacity of Brucella spp. to survive and replicate within host macrophages plays a critical role in their ability to produce disease in their mammalian hosts (8).

\section{Insights into the taxonomy and evolution of Brucella spp. gained from whole-genome sequencing}

The first Brucella genome sequences were released in the early 2000s, and their analysis confirmed the previously held ideas concerning just how closely related they were $(9,10,11)$. With the explosion in genomic sequencing, unanalysed draft sequences are being added to the databases on a regular basis, however, much of this data has yet to be analysed in the context of Brucella biology. Analysis of 42 genomes, including the type strains of all the recognised Brucella spp. and, when relevant, biovars, as well as all of 


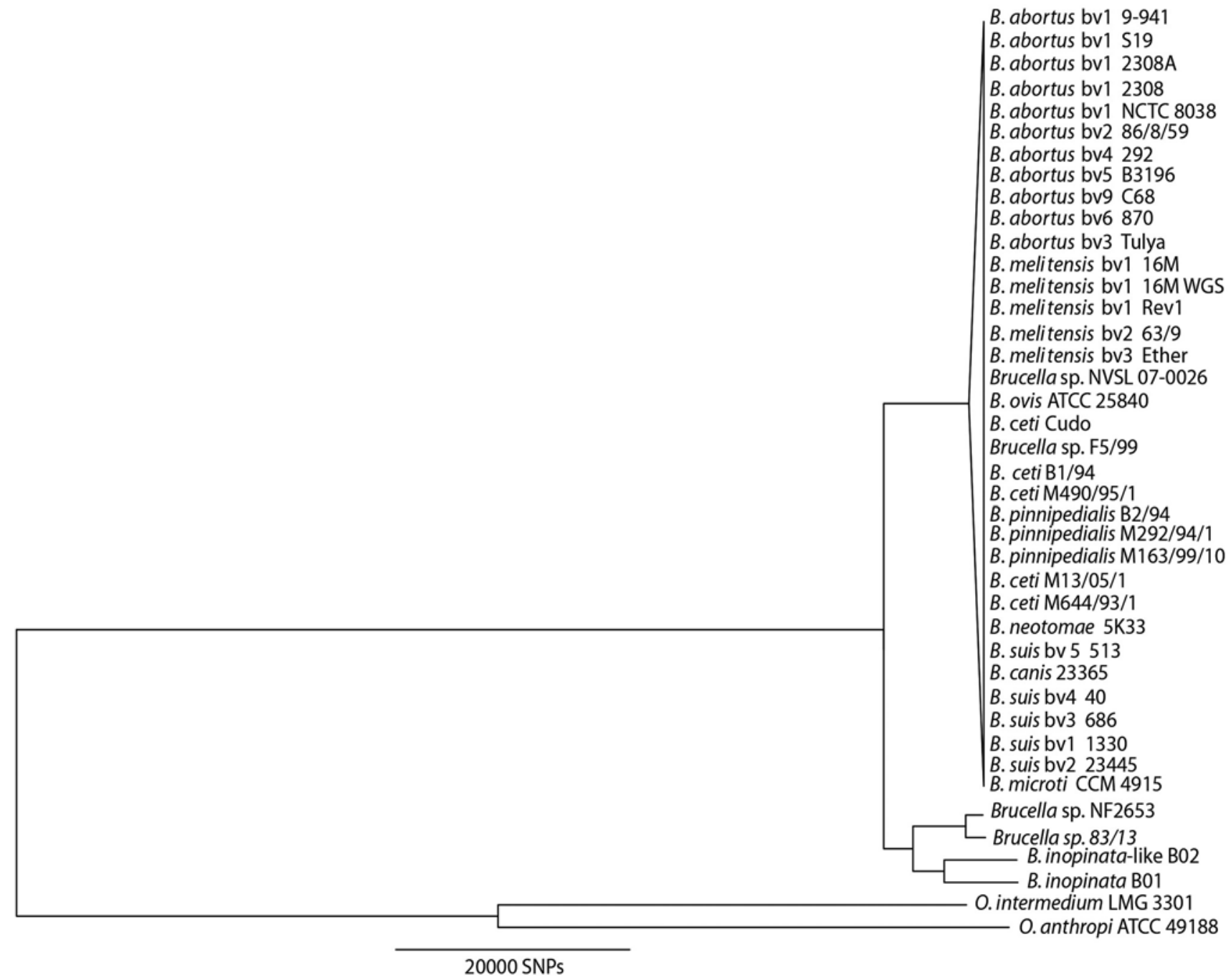

Fig. 1

\section{Phylogenetic analysis of 42 Brucella genomes}

The maximum-parsimony tree is based on 193,760 single nucleotide polymorphisms (SNPs). The early-diverging Brucella strains are clearly differentiated from the classic Brucella strains, with 2,672 SNPs unique to the classic Brucella strains and 1,172 SNPs unique to the outer clade (strains NF2653, 83/13, B01, and B02). The tree was rooted with Ochrobactrum spp. as outgroups. All branches have $100 \%$ support unless otherwise noted

the recently described unclassified strains, has clarified the evolutionary relationships in the genus (Fig. 1). The strains can be separated into two main groups that we will call the 'classical' and the 'atypical' Brucella spp. Work is ongoing by the Subcommittee on the Taxonomy of Brucella (of the International Committee on Systemics of Prokaryotes) to define standards for the genus.

The 'classical' Brucella spp. are a group that includes the Brucella species that were described first (B. melitensis, B. abortus, B. suis, B. canis, B. neotomae, B. ovis). This group also includes the marine mammal isolates (B. ceti and B. pinnepedialis) and B. microti. Despite the appellation 'classical', these strains, which were the result of an explosive radiation event, are in fact the most recent in evolutionary terms (12). The 'atypical' strains include the two recent strains isolated from unusual human cases
(B. inopinata $\mathrm{BO}$ and $\mathrm{B}$. inopinata-like $\mathrm{BO} 2$ ), as well as a group of strains isolated from Australian rodents in the 1960s that had originally been misclassified as B. suis biovar $3(12)$.

Comparison of the genomes of Brucella spp. with those of their closest phylogenetic relatives, Ochrobactrum anthropi and Ochrobactrum intermedium, provides some insight into how Brucella has evolved from being a soil bacterium, to an opportunistic pathogen, then to an intracellular stealth pathogen that causes a chronic infection. Ochrobactrum strains have a much larger genome than Brucella spp. (O. anthropi: $5.2 \mathrm{Mb}, 5,100$ genes; O. intermedium: $4.7 \mathrm{Mb}$, 4,600 genes; Brucella spp.: 3.1-3.4 Mb, 3,200-3,700 genes), showing that there has been considerable genome reduction, or parallel evolution. However, the road to virulence has also required the acquisition of new characteristics that are 
not found in Ochrobactrum, and the Brucella core genome (classical and atypical) has genes encoding 170 proteins that are not found in either of the two Ochrobactrum genomes, and a further 249 genes are unique to the classical strains. Many of these genes are found in genomic islands that may or may not be present, depending on the strain. A subset of these Brucella-specific genes are involved in intracellular survival and multiplication and allow the bacterium to obtain metal ions, such as iron, nickel and magnesium, which are important co-factors for many enzymes, but are not freely available within the host (12). The clearest virulence factor is the VirB type IV secretion system (T4SS); here, the operons encoding T4SS dedicated to conjugation found in Ochrobactrum have been lost in Brucella spp. and replaced by a virulence-dedicated system. In addition, some of the recently identified substrates of the T4SS are not found in Ochrobactrum spp. (12).

Modification of the lipopolysaccharide (LPS) was also an important step in the evolution of Brucella spp. to become pathogens of mammalian hosts; interestingly, strain $\mathrm{BO} 2$, which shows low levels of virulence in cells, has a rhamnosebased O-polysaccharide (OPS) antigen associated with the LPS which is similar to that of Ochrobactrum, while all other strains have a perosamine-based OPS antigen (13). Loss of resistance to strong acid is another consequence of genome reduction that is occurring in most of the classical Brucella spp.; this may indicate a change in transmission route from oral infection to vertical transmission in utero (12). One of the key aspects of the biology of Brucella spp. that genomic sequencing has not yet been able to fully explain is the genetic basis of the host specificity of the different Brucella spp. Based on genomic analysis to date, it is clear that the preference of different Brucella spp. for a host is not based on a specific gene or pathogenicity island, but may rather be related to small genomic changes that affect expression or function of shared genomic content. It is likely that minor differences in the physiology of the different host species of Brucella spp. also play a role in establishing the host specificity and preference of the different species.

\section{Insights into the pathology and clinical manifestations of brucellosis}

Diagnostic capabilities play a central role in implementing control measures based on the One Health concept (6), since prevention of zoonotic infections and potential human disease requires an accurate diagnosis both of animal and human infections. Recognition of clinical and pathological signs or symptoms and lesions that are compatible with brucellosis is a critical initial step towards a sound differential diagnosis.
The outcome of infection is highly dependent on the species of Brucella and the mammalian host involved (14). While Brucella spp. are not host-specific, they tend to be host-restricted, with variable ability to infect and cause disease in non-preferred hosts, including humans. Here, the focus is on disease associated with Brucella species with the highest zoonotic potential, namely B. melitensis, B. abortus, and B. suis $(14,15)$. Other Brucella spp. that are pathogenic for humans, such as B. canis, B. ceti and B. pinnipedialis, will also be briefly mentioned. Although domestic animal species are the most important source for human infections, either due to occupational risk or consumption of contaminated food (15), the potential role of wildlife for maintaining the disease will be briefly discussed. Although B. ovis is a major reproductive pathogen for sheep, it will not be included in this review since it does not cause human disease (14).

Brucella melitensis is by far the most important Brucella spp. for humans $(14,15)$. Goats are very susceptible to infection, and they are considered the primary host for B. melitensis (16). Infection usually occurs through the oral route, and the most important clinical manifestation in goats is abortion at variable stages of gestation, which is associated with lesions in the placenta and fetus (17). In bucks, infection is often associated with genital lesions (e.g. inflammation of the testis, epididymis, seminal vesicle, and deferent duct). Chronic infections are often associated with articular inflammation and hygroma formation (16). Although not all infected goats abort, they usually shed the pathogen in the environment, which poses a high risk of infection to other susceptible animal species that share the same environment (e.g. cattle and sheep), as well as for animal handlers (17). Experimental infection of goats with B. abortus demonstrated that the organism localises in the mammary gland (18), which is similar to what is observed in experimental infection of cows with B. abortus, resulting in shedding of the pathogen in the milk (14).

While bovine infections with B. melitensis are quite common in cattle raised in close contact with infected goats, cattle are the primary host for B. abortus (6). Brucella suis (mostly biovars 1,2 and 3) also infects cattle, but such infections are usually not associated with clinical signs (19). Pathogenesis of B. abortus in cattle has been thoroughly reviewed (20). The most important clinical manifestations of brucellosis in cattle are abortion during the last third of the gestation and the birth of weak calves, which is associated with high neonatal mortality rates. These clinical signs are often accompanied by fibrinous and necrotising placentitis (14), which is associated with the tropism of B. abortus for trophoblastic cells, which are highly permissive for intracellular growth of the pathogen (20). Infected fetuses often develop lesions, particularly fibrinous pleuritis and/or pneumonia and fibrinous pericarditis (14). Calves transplacentally infected or infected by ingesting contaminated milk usually 
remain asymptomatic, but they may later abort or give birth to infected calves, thus maintaining the disease in the herd (21). Infected cows also tend to have reduced milk yield, with an increase in the number of somatic cells in the milk (18), which is associated with interstitial mastitis containing intralesional B. abortus, and shedding of the pathogen in the milk (14). In bulls, B. abortus infection may be asymptomatic, but it often leads to orchitis, which may be associated with epididymitis and seminal vesiculitis. Chronic infections may progress to diffuse testicular fibrosis and permanent infertility (21).

Pigs are susceptible to $B$. suis infection, particularly biovars 1, 2 and 3. Brucellosis in pigs tends to be a more generalised, chronic, and bacteraemic disease than brucellosis caused by B. abortus in cattle (17). Brucellosis suis infection in pigs is associated with abortion, stillbirths, decreased litter size, weak piglets, infertility, orchitis and epididymitis in males. Spondylitis is common, and it is occasionally associated with paralysis. Abscesses may be observed in bones and joints (17).

Wildlife may serve as reservoirs for some of the abovementioned Brucella spp. For instance, B. suis biovar 4 naturally infects reindeer/caribou (Rangifer tarandus) and moose (Alces alces) in Siberia, Alaska and Canada (22). Similarly, B. abortus infection is common in elk (Cervus elaphus) and bison (Bison bison) in the Yellowstone Conservation Area (YCA) in the United States (23), as is B. suis in feral swine (24). Seropositivity to Brucella spp. associated with hygromas has been reported in African wildebeest (Connochaetes taurinus) and buffalo (Syncerus caffer) (25).

The genus Brucella has markedly expanded in the past few years. Among the newly described Brucella species, marine isolates, i.e. B. ceti and B. pinnipedialis, have been extensively studied and thoroughly reviewed $(26,27)$. Serological evidence of exposure to Brucella spp. has been reported in 53 marine mammal species, whereas isolation or detection of Brucella spp. genomic DNA has been reported in only 18 such species. These marine isolates are prone to induce neurobrucellosis and articular lesions, and they have documented potential for infecting humans (26).

\section{Insights into anti-Brucella immune responses}

Studies of immune responses to Brucella spp. have largely been conducted in the mouse model because of the availability of reagents and tools, including inbred strains of mice. The majority of studies have been conducted with B. abortus and B. melitensis.
While Brucella spp. live in professional phagocytes it is known that phagocytes can kill Brucella spp. if activated by the cytokine interferon- $\gamma$ (IFN- $\gamma$ ) prior to infection (28). Moreover, using gene-deleted mice it has been shown that, in the absence of IFN- $\gamma$, mice die when challenged with a virulent strain of B. abortus (29). This cytokine is produced by $\mathrm{T}$ lymphocytes. Although the principal producers and those most clearly involved in protection are the CD4 T cells, other $\mathrm{T}$ lymphocyte subpopulations that produce IFN- $\gamma$ include both CD 8 T cells and $\gamma \delta$ T cells (30), the latter of which also produce interleukin-17 (IL-17) (30), another proinflammatory cytokine. However, IL-17 does not seem to have a protective role since in its absence an increase in infection was not found (31). Similarly, while CD8 T cells can be cytotoxic (in addition to producing IFN- $\gamma$ ) and such cytotoxic cells have been demonstrated to be generated in vivo following infection, a clear role for cytotoxic cells is not evident (29). Finally, infection of human macrophages resulted in decreased major histocompatibility complex (MHC) class I molecules on the surface, and thus decreased Brucella antigen presentation to CD8 T cells and decreased killing (32).

Using wild-type mice it has been shown that infection with Brucella spp. results in a decrease in the IFN- $\gamma$ response after the first week of infection (33). The production of IFN- $\gamma$ can be partially rescued by administering recombinant interleukin-12 (IL-12) (33), which is made by cells of the innate immune system, and activation of those cells via tolllike receptors (TLRs), particularly TLR2 and TLR4 (34). The decrease in the inflammatory response following infection is mediated by cytokines most commonly associated with $\mathrm{T}$ cells, such as interleukin-10 (IL-10) (35) and TGF- $\beta$. The absence of IL-10 production by CD4 $\mathrm{T}$ cells, or the absence of its receptor, increases control of the infection and even promotes complete clearance (35). Recently, it was shown that $\mathrm{B}$ cells contribute to the production of these antiinflammatory cytokines and thus promote chronic infection, in that, in the absence of B cells, but not antibodies, there is a rapid reduction in the number of bacteria in the spleen between 10 to 14 days post-infection (36).

It has been shown that Brucella spp. actually use B cells as a niche in which to survive intracellularly, although they do not replicate in this type of cell (37). Despite a lack of replication, $10 \%$ of cells infected with Brucella spp. in vivo are B cells and are responsible for hosting 10\% of the bacteria in infected mice. Also, Brucella spp. must be opsonised (coated) with Brucella-specific IgM antibodies and complement components to enter and infect B cells. Because antigen-specific IgM is required, infection of B cells is unlikely to affect the establishment of infection until after the first week. Indeed, B-cell-deficient and B-cell-intact mice have comparable infection kinetics until ten days postinfection (36). The inability to replicate in B cells could be due to a lack of the phagosomal acidification needed 
for bacterial replication (38), a process that is critical for induction of virulence genes such as virB (39).

Some unexpected revelations have been made recently regarding both the innate and adaptive immune responses. It has been shown that neutrophils have an adverse effect on control of the infection, at least in the mouse model. In their absence there was more IFN- $\gamma$ produced and less of the Th2 cytokine IL-4. Moreover, there was a greater infiltration of macrophages and dendritic cells into the spleens of mice without neutrophils (40). Similarly surprising was the observation that the bacteria in a primary infection were controlled in the absence of antibodies as well as in their presence (36). However, it may be comforting to know that, in secondary challenge studies, antibodies do indeed provide a modicum of resistance (31), which supports the conventional wisdom.

\section{Novel serodiagnostics of brucellosis}

Laboratory-based confirmation of disease is a critical tool in the battle against brucellosis because there is an absence of specific clinical signs in either humans or animals. Although culture of Brucella spp. is the definitive diagnosis, it is difficult, dangerous and expensive to perform and the optimal samples are not always available. Molecular methods such as polymerase chain reaction (PCR) are proving useful, but direct detection of specific DNA from routinely accessible material is insufficiently reliable (41). Alternative means of immunodiagnosis, such as the skin test and IFN- $\gamma$, have still to prove themselves. They present not insignificant logistical hurdles and serology remains the easier option (42).

The first serological assay, the serum agglutination assay, was developed in 1897 and since then a number of developments and innovations have taken place. The current portfolio of internationally recognised methods includes the Rose Bengal test (RBT), the buffered plate agglutination test (BPAT), the complement fixation test (CFT), the indirect enzyme-linked immunosorbent assay (iELISA), the competitive ELISA (cELISA) and the fluorescence polarisation assay (FPA) (43). The most recent significant innovation was the development of the FPA (44), a homogeneous assay based on a purified fluorescein isothiocyanate (FITC)-conjugated OPS antigen that can be performed relatively quickly and produce quantitative data. Like the FPA, all the conventional assays rely upon the humoral immunodominance of the OPS to endow them with useful diagnostic sensitivity and specificity, as the antigens for each of these assays contain this ingredient in large amounts. However, each assay possesses, to a greater or lesser extent, the same weaknesses. These include an inability to reliably differentiate between antibodies raised by vaccination with smooth strains of Brucella spp. (45) and antibodies raised by Gram-negative bacteria in possession of a highly similar OPS structure (46). It appears that the OPS dominates the antibody repertoire to such an extent that of the many assays developed with alternative antigens none has yet to make it into routine practical use (47).

As a consequence, the fine structural elements within the Brucella OPS have recently been revisited to examine whether some of the more specific features within it may be successfully exploited. It has been known for many years that the OPS from Brucella spp. possesses epitopes, as defined by mAbs, that are not shared with the OPS from Yersinia enterocolitica O:9, which in most other respects has an almost identical structure and is the foremost suspect for the aetiology of most false-positive serological reactions (FPSRs) (48). The main structural features within some of these OPS epitopes have been identified and evaluated (49), although some that have been hypothesised remain elusive (50).

The role and value of specific OPS epitopes in serodiagnosis have been investigated. The emphasis has been on examining the influence of the occasional $\alpha 1-3$ linkage between the monosaccharide components. This is a key feature within the $\mathrm{M}$ epitope, even if this 'antigen' is not evenly distributed between the species of smooth Brucella spp. However, recent structural evidence points towards the fairly ubiquitous existence of an M-type tetrasaccharide epitope at the terminal, extracellular tip of each smooth Brucella spp. regardless of the serotype, i.e. A, M or mixed $A$ and M (51). Given the preponderance of the OPS as a surface antigen, it is feasible to consider that this particular, and as far as is known, unique, structure is a site for interaction with antibodies and B-cell receptors.

Specific oligosaccharides that match the configuration of an $\mathrm{M}$ epitope while minimising flanking regions that would otherwise create attractive A epitopes have recently been developed (52). Such specific, discrete structures are not produced in nature. The synthetic M-like oligosaccharides have been developed as diagnostic antigens in ELISA format and applied to sera from cattle that have been infected with $B$. abortus biovar 1 (A dominant) strains, sera from uninfected cattle that present FPSRs with conventional serological techniques, and sera from randomly sampled non-infected cattle. The data (J.A. McGiven and D.R. Bundle, manuscript submitted) show a highly significant increase in the capability of the developed assays to differentiate between the infected and FPSR populations - while maintaining specificity against the samples from the randomly acquired non-infected population - compared to the equivalent data derived from 'native' Brucella antigens. 
In addition to resolving the long-standing issue of FPSRs in brucellosis testing, the method also has the potential to unravel a paradox that exists in the field of vaccination. It has long been appreciated that the most protective vaccines for brucellosis are smooth strains and that elimination of the OPS has a deleterious effect in this regard - although its precise role is not well understood (53). It is equally well known that vaccination with smooth strains gives rise to antibodies that react in and confound conventional assays. This completes the paradox. Yet, the application of an M-specific diagnostic antigen in combination with a vaccine that presents A epitopes only may offer the best of both worlds: a protective vaccine that presents OPS allied with a DIVA (Differentiating Infected from Vaccinated Animals) diagnostic that detects antibodies due to infections with Brucella spp. in possession of the $\mathrm{M}$ epitope. Only one Brucella biovar from the significant smooth species is known not to possess this epitope and this, rather intriguingly, is B. suis biovar 2 (54).

Somewhat fortuitously (or is it possible that the following properties may have some causal association with the atypical OPS structure?) B. suis biovar 2 infects but does not cause brucellosis in ruminants and is self-limiting (55). It also appears to be non-pathogenic for humans (56). Could this be an interesting starting point in the search for a new generation of brucellosis vaccine(s) for a DIVA strategy?

\section{Brucellosis in terrestrial wildlife}

The link between wildlife and many diseases in livestock is now well recognised. The long-standing conflict between wildlife conservationists, on the one hand, and animal health authorities and livestock owners, on the other, is largely based on differing strategies implemented to control diseases shared by livestock and wildlife. The creation of new interfaces between livestock and wildlife due to human activity is the most important factor in disease transmission (57).

In the United States, responsibility for wildlife diseases is complex and can encompass both state and federal agencies. However, in general, transport of wildlife across state boundaries requires compliance with regulations for disease control programmes for domestic livestock. Brucellosis control efforts for cattle in the United States began in 1934 and formally became an eradication programme in 1954. Currently, regulatory efforts rely on serological surveillance and removal of seropositive animals, and vaccination of prepubescent females deemed to be at risk of infection.

At the present time, approximately 6,000 bison in YCA and Grand Teton National Park, and approximately 120,000 elk in the states of Wyoming, Montana and Idaho, are the primary concern in regards to persistence of B. abortus in a wildlife reservoir. Seroprevalence of brucellosis in YCA bison is approximately 50\% and data suggest that $B$. abortus can be isolated from approximately $46 \%$ of seropositive bison (58). Seroprevalence in elk varies, depending on their association with winter feedgrounds, but recent data suggest that the epidemiological features of elk brucellosis may be changing as seropositive elk are being detected in new areas of the YCA. In regards to brucellosis in bison and elk, the origin of infection is believed to be infected domestic livestock brought into the area more than 100 years ago. Control of disease in elk and bison populations is impaired by difficulties in catching and handling wildlife, species differences in immune responses to vaccines, lack of an efficacious brucellosis vaccine that can be effectively delivered, and changes in demographics and land management within the YCA. Because of the estimated cost and concerns regarding the impact of vaccination on behaviour, the National Park Service, which has responsibility for management of bison in YCA has indicated a desire for a vaccine that is highly efficacious in bison and capable of being delivered remotely before implementation of a costly vaccination programme. Currently, transmission of brucellosis in YCA is prevented by spatial and temporal separation between wildlife and cattle, and implementation of mandatory calfhood and adult vaccination of cattle in high-risk areas. Regardless, the persistence of brucellosis in wildlife in this area has led to at least 22 cases in which brucellosis has been transmitted to livestock in the YCA over the last 11 years, with elk being implicated as the source of infection in all instances.

Knowledge of the pathogenesis of brucellosis in bison and elk, and immune responses to vaccination, has increased. When compared to cattle, naive bison are more susceptible to infection and are more likely to abort after experimental challenge during pregnancy (59). Bison also take almost twice as long as cattle to clear the attenuated B. abortus RB51 vaccine strain from lymphatic tissues (24 and 12 weeks, respectively) $(60,61)$. In comparison, the RB51 vaccine strain has been demonstrated in the lymphatic tissues of elk beyond 40 weeks after vaccination (S. Olsen, unpublished data). Although bison immune responses to brucellosis vaccination are generally comparable to those of cattle, peak IFN- $\gamma$ production to Brucella antigens under in vitro conditions is delayed in bison as compared to cattle (S. Olsen, unpublished data). Elk demonstrate distinct immunological differences after vaccination with smooth or rough strains of B. abortus, with immune responses that are primarily humoral with poor or limited stimulation of cellular immunity (62). This may explain why studies with smooth and rough vaccine strains have failed to demonstrate adequate protection in elk against experimental Brucella challenge $(63,64)$. Experimental data also suggest differences between elk and cattle in the rate of abortion after experimental challenge, which may be related to immunological differences (S. Olsen, unpublished data). An ideal vaccine to address brucellosis in bison and elk 
in the YCA would induce protective immunity after one inoculation, be clinically and environmentally safe, and be capable of being remotely administered.

Free-ranging and farmed caribou in Alaska are another reservoir for brucellosis, with numerous older reports documenting B. suis biovar 4 transmission to humans. Serological evidence from as early as 1939 suggested brucellosis in Alaska Natives. Alaska reported an average of one human case of brucellosis per year from 1958 to 1980 and a total of seven cases between 1982 and 2010, with at least three of the later infections attributed to B. suis biovar 4 infections of caribou (65). In Alaska, almost twothirds of the estimated 18,000 reindeer in the state are found in the Seward Peninsula (66). Since enactment of the 1937 Reindeer Act, only Alaska Natives or native village governments are allowed to own reindeer. A number of vaccines have been tried on a small scale and with limited success in reindeer. At the present time, except for sporadic serological surveillance and very limited use of a killed B. suis biovar 4 vaccine, there are no significant regulatory activities occurring in relation to brucellosis in farmed reindeer in Alaska.

\section{The changing epidemiology of brucellosis}

The biological nature of Brucella spp. allows persistence in various hosts and environments, leading to different modes of transmission, e.g.:

- silent transmission in marine wildlife reservoirs, with no or minimal signs of the disease in animals which coevolved with the bacterium, and with fish or invertebrates as a possible source of infection (67)

- spillover from terrestrial wildlife reservoirs to livestock and thence to humans (6)

- persistence in soil $(68,69)$

- active transmission to rodents (70) or potentially to coldblooded hosts (71).

An important shortcoming of brucellosis serology is its inability to determine which (smooth) Brucella spp. induce antibodies in the animal or human host. Indeed, the Brucella OPS carries the immunodominant epitopes that are shared by B. abortus, B. melitensis and B. suis and virtually all serological tests for detecting anti-OPS antibodies (such as the OIE prescribed tests) use B. abortus OPS antigens (72). As a consequence, infection in mammalian hosts, including humans, with B. abortus, B. melitensis or B. suis, will induce the same serological pattern, and antibodies induced by these different Brucella species are actually detected by the same serological tests. The obvious consequence is that sound epidemiological inferences are very difficult to make in the presence of seropositivity in multiple species of animals. Such shortcomings have recently been extensively reviewed and highlighted (6). Nowadays, B. melitensis and B. suis infections in cattle are described in different continents with different implications in terms of regulatory issues and veterinary public health, i.e. transmission of $B$. melitensis and B. suis biovar 1 via milk (6). In the Southern US states, there is a high prevalence of $B$. suis biovar 1 infection in feral swine (73). Importantly, feral swine have also been found infected with B. abortus, even if they have had no contact with cattle for decades (24). The changing epidemiology of brucellosis is described below.

\section{Brucella melitensis and Brucella suis infections in cattle}

Brucella melitensis infection in cattle has been reported in France (74) and Spain (75) in areas where B. melitensis was found in its preferential hosts, i.e. sheep and goats. The occurrence of this in the developing world was further illustrated by a recent study in Egypt, in which cattle and water buffalo (Bubalus bubalis) kept in a household with sheep and goats had 6.32 times the odds of testing seropositive for Brucella spp., compared to cattle and water buffalo that were not (76). This clearly suggests that cattle and water buffalo were infected with B. melitensis. However, this could not be confirmed, as there were no attempts to isolate the species involved. Recently, another study carried out in Egypt has highlighted the need to identify which Brucella species are infecting different livestock species and to define transmission patterns in order to adopt the most suitable control strategies. This study of brucellosis in small ruminants in Egypt found strains of both B. abortus and $B$. melitensis, but, in addition, isolates from two cows were unexpectedly identified as B. suis (77). Importantly, B. suis biovar 1 was isolated from milk in one cow, which represents an additional veterinary public health issue.

Brucella suis biovar 1 has been regularly isolated from cattle in the United States (19) and is becoming an emerging problem in South America (78). Transmission of B. suis biovar 1 by feral swine to cattle has become a significant regulatory issue, as transmission appears to occur from contact when feral swine compete for grain in cattle feeding areas. It is worth reiterating that cattle infected with $B$. suis cannot be serologically distinguished from cattle infected with B. abortus. In China, an attenuated B. suis biovar 1 strain named Brucella suis strain 2 is used as an oral vaccine in cattle, small ruminants and pigs. Although its efficacy has never been demonstrated and its use is not recommended by the OIE, it is still widely used in China (79). It has recently been isolated from cattle (80). Lastly, B. suis biovar 2 has recently been isolated from cattle in Belgium (55). Brucella suis biovars 1, 2 and 3 are not considered 
to be pathogens in cattle $(19,55)$. Importantly, B. suis biovars 1 and 3 are true pathogens for humans, whereas B. suis biovar 2 is not (56).

\section{Brucella suis and Brucella abortus infections in feral swine}

Feral swine (Sus scrofa) are rapidly expanding their ranges across the United States, with at least 44 of 50 states reporting populations. The rapid expansion into new areas has primarily been caused by unregulated human transportation of feral swine to establish new populations for hunting. In at least 14 states, brucellosis has been documented to be present in feral swine, with some populations demonstrating high seroprevalence (81). Brucellosis in feral swine has been implicated as the cause of $B$. suis infections in humans in a number of cases in the United States (82). With the exception of production systems which allow contact with feral swine, brucellosis has been eliminated in most domestic swine herds. As behaviour and topography make complete elimination of feral swine unachievable in most areas with established populations, regulatory control of feral swine brucellosis is currently based on establishing effective separation from domestic livestock, and population control by hunting or targeted depopulation efforts. Any vaccine considered for field use in feral swine would need to be efficacious after remote delivery, with delivery via oral baits being ideal. Any vaccine for feral swine would also need to be environmentally safe, and clinically safe in non-target species.

It should be noted that maintenance of $B$. abortus has also been documented in feral swine, including feral swine that had been spatially separated from domestic livestock for decades (24). The epidemiological consequences of these findings are important. Indeed, B. abortus would have been able to perform a 'host species jump' and conditions for the establishment of a true reservoir of B. abortus in feral swine need to be experimentally assessed. Furthermore, the mechanisms that enabled this species jump should be identified in order to shed light on the mechanisms that determine host specificity.

\section{Mixed herds and nomadism}

Mixed herding, particularly raising sheep and/or goats along with cattle, was reported by many researchers to be a risk factor for Brucella transmission between different animal species. However, transmission does not occur in both directions to the same extent. Indeed, whereas infection of sheep and goats with B. abortus is seldom reported (83), B. melitensis infection in cattle has regularly been reported. Studies performed in sub-Saharan Africa suggest that cattle are a significant source of Brucella infection for humans. It is not yet known if cattle are mainly infected with $B$. melitensis, as suggested by research in North Africa (84), or with
B. abortus, as indicated by studies in Zimbabwe (85), or with both Brucella species, as recently described in Kenya (86). Additionally, the recent occurrence of B. suis infection in cattle in Egypt highlights the urgent need to study brucellosis in pigs in Africa (77); to date no documented report on its isolation in pigs in Africa is available in the international literature.

\section{Brucella abortus and Brucella melitensis infections in camelids}

Camelids represent by far the most important livestock species after cattle, small ruminants, pigs and poultry. The home ranges of dromedary (Camelus dromedaries) are the hot and dry regions of North Africa, Ethiopia, the Near East and West-Central Asia, whereas the bactrian camel (Camelus bactrianus) occupies the cold deserts of southern areas of the former Soviet Union, Mongolia, East-Central Asia and China. The habitats of the limeades (genus Lama) are the cold heights of Latin America (87). To date, brucellosis has not been detected in limeades (78). It is worth mentioning that B. abortus and B. melitensis have been detected in supramammary lymph nodes in camels in Darfur, Western Sudan, and this presents a potential hazard to those who consume raw camels' milk, a common practice in nomadic camel owners (88). However, it is not known if camelids can sustain a B. melitensis or a B. abortus infection without a constant influx of bacteria from their true reservoir species (6).

\section{Brucella ceti and Brucella pinnipedialis infections in marine mammals}

Recently, two independent studies suggest that hooded seals are not the definitive host of $B$. pinnipedialis $(67,89)$. Indeed, gross pathology associated with B. pinnipedialis infection has not been described in seals and vertical transmission is not likely to occur, since B. pinnipedialis has never been isolated from females of reproductive age. These studies point toward the existence of a reservoir of Brucella spp. in the aquatic environment, likely in the food web. Fish constitute a significant part of the diet of seals. Further studies are needed to determine if fish, or other aquatic organisms that are part of the diet of seals, can sustain a B. pinnipedialis infection.

There have been three reported cases of natural human infection associated with Brucella spp. from marine mammals (see next section). They were all associated with Brucella sequence type (ST) 27, although no contact with marine mammals was reported (90). Brucella ST27 has, however, been isolated along the Californian coast in a dolphin and in a fur seal. Comparative phylogenomics indicates that Brucella ST27 (Brucella sp. F5/99 and B. ceti Cudo) cluster separately within the marine mammal Brucella spp. group $(12,91,92)$. 
Altogether, this suggests that there is a reservoir of Brucella spp. in the aquatic environment, possibly in fish or other aquatic organisms, and that these Brucella spp. may spill over to marine mammals and humans.

\section{Zoonotic brucellosis}

Despite the high percentage of zoonotic pathogens, patients suffering from fever of unknown origin are often misdiagnosed and the prevalence of acute bacterial zoonoses is underestimated by medical doctors, even in endemic regions (93).

Human brucellosis is mainly prevented by controlling the health status of livestock, principally through surveillance, continuous monitoring and culling of infected animals, wildlife exposure control and vaccination. Furthermore, import/export regulations for animals and animal products from endemic regions as well as food hygiene measures counteract human infections.

Vaccination of livestock can be a rapid and relatively inexpensive intervention to prevent brucellosis in humans, and mass vaccination programmes in small ruminants resulted in a significant decline in the incidence of the zoonotic disease in the human population in Greece (94). A reduction of human brucellosis cases was nearly immediately achieved by reducing bovine brucellosis in South Korea (95).

Currently, domestic animals, mainly small ruminants, play the key role in transmitting the disease to humans and, to date, animals are the only known source of human infection. The human pathogenic Brucella spp. are transmitted within their reservoir species either vertically, via the placental route and milk, or horizontally, via genital contact or aborted fetuses (96). Humans may acquire brucellosis directly by animal contacts or indirectly by ingestion of contaminated food products, such as unpasteurised milk and cheese or raw meat, or by inhalation of aerosolised particles both from animal secretions or excreta and from laboratory cultures. Humanto-human transmission has rarely been reported, so humans are generally considered to be incidental or dead-end hosts for Brucella (96).

The majority of reported human cases are caused by B. melitensis, followed by B. abortus, then B. suis (biovars 1,3 and 4). Brucella melitensis (biovars 1 to 3 ) is the causative agent of ovine and caprine brucellosis. However, B. melitensis is not restricted to a single host and also infects animals such as cattle and other bovidae, camelids and fish $(97,98)$. The severity of clinical signs and symptoms in human brucellosis seems to be independent of the species, at least, it does not differ between B. abortus and B. melitensis infections (99). Furthermore, attenuated live vaccine strains used in eradication and control programmes may also cause human infections comparable to those caused by the wildtype field isolates. The comparable impact of the various species on human health may be due to the highly similar genomes of human pathogenic Brucella spp. (11). Hence, the significant differences in host preference might rather be explained by gene regulation than by gene configuration (69). Classical virulence factors are missing in Brucella spp. and metabolic abilities are thought to be responsible for pathogenicity, e.g. B. abortus, B. melitensis and B. suis encode for a urease that is essential to withstand the low $\mathrm{pH}$ in the stomach. Brucella ovis lacks this enzyme and is not able to cause foodborne infection in humans (96). Zoonotic concerns regarding marine mammal strains were initially raised following the recovery of a cetacean strain of Brucella spp. from a laboratory worker at the Animal Health and Veterinary Laboratories Agency at Weybridge in the United Kingdom, who had seroconverted after suffering from headaches, lassitude and severe sinusitis (100). In April 2003, the first report of community-acquired human infections with marine-mammal-associated Brucella spp. was published. The authors described the identification of these strains in two patients with neurobrucellosis and intracerebral granulomas. Despite a more than 15-year separation, these cases have similarities: both patients were from Peru and denied significant exposure to marine mammals (101). In 2006, the isolation and characterisation of a marine Brucella strain from a New Zealand patient, who had not previously been exposed to marine mammals, was also reported (102).

\section{Concluding remarks and perspectives}

Controlling B. abortus infection in cattle and B. melitensis infection in small ruminants remains the most effective means of mitigating the brucellosis burden in humans. This is achieved by standard veterinary public health measures, such as vaccination, and was demonstrated in Greece in the 1990s (94). Such measures have only rarely been assessed from a One Health perspective, with the exception of the rough estimation of the benefits to human health of livestock vaccination in Mongolia (103). Nowadays, human brucellosis remains a major public health problem in the Middle East (104) and in China, where its incidence has risen dramatically since the beginning of the 21st Century (105). Thus, the sound implementation of veterinary public health measures remains key for mitigating the risks of transmission to humans. To what extent a One Health approach will enhance standard veterinary public health measures remains to be defined and documented. Indeed, from the human health perspective, zoonotic diseases are of minor concern when compared to 'lifestyle diseases', such 
as obesity, hypertension, cardio-vascular diseases or cancer, unless they have pandemic potential and a huge economic impact. Likewise, in terms of the profitability of animal production, zoonotic diseases represent only a fraction of the global disease burden (5).

When bovine brucellosis is controlled or eradicated, FPSRs due to cross-reactivity linked to epitopes associated with the LPS emerge as the main regulatory problem, particularly in Europe. Until recently, no available serological test could discriminate beyond any doubt between FPSRs and infection with B. abortus in cattle. All approaches based on the detection of antibodies directed towards protein have so far failed (106). For the first time in more than two decades, the developed assays based on the use of the $M$ epitope as antigen have the capability to differentiate between infection and FPSRs (J.A. McGiven and D.R. Bundle, manuscript submitted). Moreover, the fact that this epitope is absent in B. suis biovar 2, that this biovar is self-limiting and does not induce pathology in ruminants (56) and that it is not zoonotic opens the door for a new generation of vaccines, based on $B$. suis biovar 2, that can be used in a DIVA strategy.

Brucella suis infection in pigs is an emerging problem in Latin America, with recent reports of human brucellosis, particularly in abattoir workers (107). It is worth noting that porcine brucellosis is not a reportable disease and hence, centrally organised control or eradication programmes are not implemented. Nevertheless, brucellosis has been eradicated in the vast majority of intensive pig production systems in the developed world. It is also worth noting that half of the world pig population is housed in China, where information on the prevalence of brucellosis in pigs is limited (108). However, B. suis biovar 3 infection in humans has been reported in Guangdong Province in China (109), suggesting that brucellosis has not been efficiently controlled and that it impacts on human health.

The fact that B. abortus, B. melitensis and B. suis are isolated from non-preferential hosts more and more frequently indicates shortcomings in control programmes and/or changes in husbandry practices or wildlife management. For example, the isolation of $B$. suis in cattle may be due to the rise in the density of domestic, free-roaming and wild pig populations, resulting in enhanced transmission possibilities. Transmission is also due to the lack of biosafety precautions taken during hunting, as recently described in Belgium (55). Such infections are considered spillover infections from the true reservoir of Brucella spp. and are not sustained persistent infections in non-preferential hosts, unless there is a constant flow of Brucella spp. from the true reservoir host. As mentioned earlier, maintenance of $B$. abortus has also been documented in feral swine populations (24), with one of these populations being spatially separated from cattle for decades. If such a species jump occurred in YCA with the establishment of a true
B. abortus reservoir in elk in YCA, this needs to be addressed too. In the absence of a safe and efficient vaccine for wildlife, the management of brucellosis in wildlife is based on a spatio-temporal separation between infected wildlife and livestock when infected animals become infectious (i.e. when abortion occurs).

Wildlife may become intermediate or amplifier hosts from which Brucella spp. can spill over into livestock and humans. In France, B. melitensis has been isolated from an Alpine ibex (Capra ibex) and has probably spilled over to cattle and from cattle to humans (110). In Argentina, B. suis has been isolated in armadillos (Chaetophractus villosus), but spillover from armadillos to livestock and humans has not yet been reported (111).

In the developing world, the recent work done in Egypt illustrates the importance of moving away from epidemiological inquiries relying solely on serology. Indeed, the isolation of B. melitensis and B. suis, in addition to $B$. abortus, in cattle, is of the utmost importance in understanding new transmission routes between animal species and in designing and implementing sound strategies mitigating the risk of human infections (77).

The presence of Brucella spp. in the marine environment, particularly in the food web of marine mammals, is also of importance. Fish and other aquatic organisms may actually be the true reservoirs of marine mammal Brucella spp. Given the zoonotic potential of some of these Brucella spp., their infection biology needs to be urgently deciphered.

Recent studies have contributed greatly to our understanding of the survival strategies of Brucella spp. within hosts and other, stressful, environments. However, determinants of host specificity have not yet been identified, which remains one of the most important research issues. Indeed, this will bring important insight into how and why a given host species is a reservoir able to sustain an enzootic infection or a spillover of a given Brucella spp.

Since brucellosis does not respect borders, be they species or geographic, intersectoral collaboration across the fields of medicine, veterinary medicine and social science is indispensable (112). At the moment, the One Health approach is primarily driven by veterinarians, with only limited involvement of physicians (112). The relevance of real-time syndromic surveillance in doctors' practices or hospitals to uncover zoonotic outbreaks in livestock or intentional releases of highly pathogenic agents such as Brucella spp. is underestimated (113). Public health may benefit from a vivid exchange of information between veterinarians and medical doctors and vice versa.

However, the degree of scientific and intersectoral collaboration needed for a true One Health approach to brucellosis control has yet to be determined. The perspectives 
will be different according to the epidemiological situation, and the socio-cultural and economic environments. The socio-cultural (113) and economic (103) dimensions of brucellosis have been addressed elsewhere. It is worth noting that, in the Mongolian study, the authors report that only B. melitensis was isolated from human patients. This information suggests that human cases related to cattle contacts have resulted in B. melitensis infection. Bovines are not considered to be maintenance hosts for B. melitensis (6), the actual source of $B$. melitensis is to be found in its reservoir species, i.e. small ruminants. Unfortunately, transmission between small ruminants and cattle was omitted in the model of animal-to-human brucellosis transmission in Mongolia (114). This raises question marks about the validity of such a model.

Whatever approach is taken to brucellosis control, the infection biology of Brucella spp. should not be overlooked or wrongly understood. Indeed, this knowledge must always be integrated so that confidence in a true One Health perspective of brucellosis will be enhanced.

\title{
La recherche d'une authentique perspective "Une seule santé "s sur la brucellose
}

\author{
J. Godfroid, X. DeBolle, R.M. Roop 2nd, D. O'Callaghan, R.M. Tsolis, \\ C. Baldwin, R.L. Santos, J. McGiven, S. Olsen, I.H. Nymo, A. Larsen, \\ S. Al Dahouk \& J.J. Letesson
}

\begin{abstract}
Résumé
"Une seule santé " se réfère à une collaboration pluridisciplinaire visant à atténuer les risques pour la santé publique imputables aux micro-organismes présents chez les animaux et transmissibles à l'homme. La collaboration scientifique et l'intégration sectorielle requises pour chaque type de maladie zoonotique varient en fonction de l'amélioration sanitaire attendue de la démarche " Une seule santé " et des bénéfices économiques qui peuvent en résulter. En effet, ce n'est pas du tout la même chose d'atténuer les risques zoonotiques liés à des maladies émergentes à potentiel pandémique et d'atténuer les risques liés à une maladie zoonotique endémique comme la brucellose. De même, les opérations de gestion de la brucellose à l'interface entre les animaux sauvages et le bétail dans les zones de protection de la faune sauvage sont par essence différentes des mesures d'atténuation du risque de transmission d'une espèce donnée de Brucella au sein de ses espèces hôtes préférentielles, mesures elles-mêmes différentes de celles visant à atténuer le risque de passage d'une espèce donnée de Brucella à des espèces d'hôtes incidents, parmi lesquelles l'espèce humaine. Les modèles économiques de la brucellose ont tendance à simplifier à outrance, voire à surévaluer ou sous-évaluer la transmission entre les hôtes réservoirs et les hôtes incidents. En outre, les répercussions autres que celles liées aux marchés ne sont pas toujours correctement évaluées ; c'est le cas d'aspects tels que l'évitement de la maladie chez l'homme, la confiance des consommateurs et la biologie de la conservation. Partant, l'incertitude est telle que les prédictions économiques de ces modèles sont sujettes à caution. La connaissance de la biologie de l'infection par Brucella spp. s'avère donc une condition préalable. Les auteurs examinent et soulignent les caractéristiques essentielles de la biologie de l'infection par Brucella spp. ainsi que les changements intervenus dans l'épidémiologie de la brucellose qui doivent être pris en compte dans une authentique perspective "Une seule santé " sur cette maladie.
\end{abstract}

\section{Mots-clés}

Biologie de l'infection - Brucella spp. - Brucellose - Diagnostic - Épidémiologie Immunité - Résistance - Spécificité d'hôte - Une seule santé - Zoonose. 


\title{
La búsqueda de una respuesta a la brucelosis basada realmente en «Una sola salud»
}

\author{
J. Godfroid, X. DeBolle, R.M. Roop 2nd, D. O'Callaghan, R.M. Tsolis, \\ C. Baldwin, R.L. Santos, J. McGiven, S. Olsen, I.H. Nymo, A. Larsen, \\ S. Al Dahouk \& J.J. Letesson
}

\section{Resumen}

La noción de "Una sola salud" presupone una labor de colaboración interdisciplinar destinada a reducir los riesgos para la salud humana que plantean microorganismos presentes en especies animales capaces de transmitirse al hombre y causarle enfermedades. Para diferentes tipos de enfermedades zoonóticas se necesitan distintos grados de colaboración científica e integración sectorial, dependiendo de los beneficios sanitarios (y beneficios económicos conexos) que quepa esperar de los planteamientos de "Una sola salud». En efecto, no es lo mismo reducir el riesgo zoonótico derivado de enfermedades emergentes potencialmente pandémicas que mitigar riesgos ligados a enfermedades zoonóticas endémicas como la brucelosis. Análogamente, combatir la brucelosis en la interfaz entre animales salvajes y ganado doméstico en zonas de fauna salvaje protegida tiene poco que ver, en esencia, con reducir la transmisión de una especie de Brucella dentro de su especie hospedadora preferente, lo que a su vez tampoco es lo mismo que contener la extensión de una especie de Brucella a anfitriones no preferentes, en particular el ser humano. Los modelos económicos de la brucelosis suelen simplificar en exceso y/o evaluar erróneamente la transmisión de brucelas de anfitriones que ejercen de reservorio a anfitriones no preferentes, que constituyen así un vector de extensión. Además, a veces no cifran correctamente los resultados que carecen de valor de mercado, como el hecho de evitar contagios humanos, la confianza del consumidor 0 aspectos ligados a la biología de la conservación. Como consecuencia, existe tal nivel de incertidumbre que es posible cuestionar las predicciones económicas de dichos modelos. Por todo ello, entender la biología de la infección de las especies de Brucella es un requisito previo indispensable. Los autores examinan y destacan una serie de importantes características de la biología infectiva de las brucelas y de su cambiante epidemiología que deben ser integradas en una respuesta a la brucelosis que se base realmente en los postulados de "Una sola salud».

\section{Palabras clave}

Biología de la infección - Brucella spp. - Brucelosis - Diagnóstico - Epidemiología Especificidad por el anfitrión - Inmunidad - Resistencia - Una sola salud - Zoonosis.

\section{References}

1. Childs J.E., Richt J.A. \& Mackenzie J. (2007). - Introduction: conceptualizing and partitioning the emergence process of zoonotic viruses from wildlife to humans. Curr. Top. Microbiol. Immunol., 315, 1-31.

2. Woolhouse M.E.J. \& Gowtage-Sequeria S. (2005). - Host range and emerging and reemerging pathogens. Emerg. infect. Dis., 11 (12), 1842-1847.
3. Cleaveland S., Laurenson M.K. \& Taylor L.H. (2001). Diseases of humans and their domestic mammals: pathogen characteristics, host range and the risk of emergence. Philos. Trans. roy. Soc. Lond., B, biol. Sci., 356 (1411), 991-999.

4. Jones K.E., Patel N.G., Levy M.A., Storeygard A., Balk D., Gittleman J.L. \& Daszak P. (2008). - Global trends in emerging infectious diseases. Nature, 451 (7181), 990-993. 
5. Hasler B., Gilbert W., Jones B.A., Pfeiffer D.U., Rushton J. \& Otte M.J. (2013). - The economic value of One Health in relation to the mitigation of zoonotic disease risks. Curr. Top. Microbiol. Immunol., 365, 127-151.

6. Godfroid J., Al Dahouk S., Pappas G., Roth F., Matope G., Muma J., Marcotty T., Pfeiffer D. \& Skjerve E. (2013). - A 'One Health' surveillance and control of brucellosis in developing countries: moving away from improvisation. Comp. Immunol. Microbiol. infect. Dis., 36 (3), 241-248.

7. World Organisation for Animal Health (OIE) (2012). Chapter 2.4.3. Bovine brucellosis. In Manual of Diagnostic Tests and Vaccines for Terrestrial Animals, 7th Ed. OIE, Paris.

8. Roop R.M., Gaines J.M., Anderson E.S., Caswell C.C. \& Martin D.W. (2009). - Survival of the fittest: how Brucella strains adapt to their intracellular niche in the host. Med. Microbiol. Immunol., 198 (4), 221-238.

9. Paulsen I.T., Seshadri R., Nelson K.E., Eisen J.A., Heidelberg J.F., Read T.D., Dodson R.J., Umayam L., Brinkac L.M., Beanan M.J., Daugherty S.C., Deboy R.T., Durkin A.S., Kolonay J.F., Madupu R., Nelson W.C., Ayodeji B., Kraul M., Shetty J., Malek J., Van Aken S.E., Riedmuller S., Tettelin H., Gill S.R., White O., Salzberg S.L., Hoover D.L., Lindler L.E., Halling S.M., Boyle S.M. \& Fraser C.M. (2002). - The Brucella suis genome reveals fundamental similarities between animal and plant pathogens and symbionts. Proc. natl Acad. Sci. USA, 99, 13148-13153.

10. DelVecchio V.G., Kapatral V., Redkar R.J., Patra G., Mujer C., Los T., Ivanova N., Anderson I., Bhattacharyya A., Lykidis A., Reznik G., Jablonski L., Larsen N., D'Souza M., Bernal A., Mazur M., Goltsman E., Selkov E., Elzer P.H., Hagius S., O'Callaghan D., Letesson J.J., Haselkorn R., Kyrpides N. \& Overbeek R. (2002). - The genome sequence of the facultative intracellular pathogen Brucella melitensis. Proc. natl Acad. Sci. USA, 99, 443-448.

11. Halling S.M., Peterson-Burch B.D., Bricker B.J., Zuerner R.L., Qing Z., Li L.L., Kapur V., Alt D.P. \& Olsen S.C. (2005). Completion of the genome sequence of Brucella abortus and comparison to the highly similar genomes of $B$. melitensis and B. suis. J. Bacteriol., 187, 2715-2726.

12. Wattam A.R., Foster J.T., Mane S.P., Beckstrom-Sternberg S.M., Beckstrom-Sternberg J.M., Dickerman A.W., Keim P., Pearson T., Shukla M., Ward D.V., Williams K.P., Sobral B.W., Tsolis R.M., Whatmore A.M. \& O'Callaghan D. (2014). Comparative phylogenomics and evolution of the brucellae reveal a path to virulence. J. Bacteriol., 196 (5), 920-930.

13. Wattam A.R., Inzana T.J., Williams K.P., Mane S.P., Shukla M., Almeida N.F., Dickerman A.W., Mason S., Moriyon I., O'Callaghan D., Whatmore A.M., Sobral B.W., Tiller R.V., Hoffmaster A.R., Frace M.A., De Castro C., Molinaro A., Boyle S.M., De B.K. \& Setubal J.C. (2012). Comparative genomics of early-diverging Brucella strains reveals a novel lipopolysaccharide biosynthesis pathway. Mbio, 3 (6), e00246.
14. Xavier M.N., Paixao T.A., Poester F.P., Lage A.P. \& Santos R.L. (2009). - Pathological, immunohistochemical and bacteriological study of tissues and milk of cows and fetuses experimentally infected with Brucella abortus. J. comp. Pathol., 140 (2-3), 149-157.

15. Franco M.P., Mulder M., Gilman R.H. \& Smits H.L. (2007). Human brucellosis. Lancet infect. Dis., 7 (12), 775-786.

16. Enright F.M. (1990). - The pathogenesis and pathobiology of Brucella infection in domestic animals. Chapter 12. In Animal brucellosis (K. Nielsen \& J.R. Duncan, eds). CRC Press, Boca Raton, Florida, 301-320.

17. Poester F.P., Samartino L.E. \& Santos R.L. (2013). Pathogenesis and pathobiology of brucellosis in livestock. In Brucellosis: recent developments towards 'One Health' (G. Plumb, S. Olsen \& G. Pappas, eds). Rev. sci. tech. Off. int. Epiz., 32 (1), 105-115.

18. Meador V.P., Deyoe B.L. \& Cheville N.F (1989). - Pathogenesis of Brucella abortus infection of the mammary gland and supramammary lymph node of the goat. Vet. Pathol., 26 (5), 357-368.

19. Ewalt D.R., Payeur J.B., Rhyan J.C. \& Geer P.L. (1997). - Brucella suis biovar 1 in naturally infected cattle: a bacteriological, serological, and histological study. J. vet. diagn. Invest., 9 (4), 417-420.

20. Carvalho Neta A.V., Stynen A.P., Paixao T.A., Miranda K.L., Silva F.L., Roux C.M., Tsolis R.M., Everts R.E., Lewin H.A., Adams L., Carvalho A.F., Lage A.P. \& Santos R.L. (2008). - Modulation of the bovine trophoblastic innate immune response by Brucella abortus. Infect. Immun., 76 (5), 18971907.

21. Plommet M., Fensterbak R., Renoux G., Gestin J. \& Philippon A. (1973). - Brucellose bovine experimentale. Ann. Rech. vét., 4 (3), 419-435.

22. Forbes L.B. (1991). - Isolates of Brucella suis biovar 4 from animals and humans in Canada, 1982-1990. Can. vet. J., 32 (11), 686-688.

23. Scurlock B.M. \& Edwards W.H. (2010). - Status of brucellosis in free-ranging elk and bison in Wyoming. J. Wildl. Dis., 46 (2), 442-449.

24. Stoffregen W.C., Olsen S.C., Wheeler C.J., Bricker B.J., Palmer M.V., Jensen A.E., Halling S.M. \& Alt D.P. (2007). Diagnostic characterization of a feral swine herd enzootically infected with Brucella. J. vet. diagn. Invest., 19 (3), 227-237.

25. Waghela S. \& Karstad L. (1986). - Antibodies to Brucella spp. among blue wildebeest and African buffalo in Kenya. J. Wildl. Dis., 22 (2), 189-192.

26. Hernández-Mora G., Palacios-Alfaro J.D. \& González-Barrientos R. (2013). - Wildlife reservoirs of brucellosis: Brucella in aquatic environments. In Brucellosis: recent developments towards 'One Health' (G. Plumb, S. Olsen \& G. Pappas, eds). Rev. sci. tech. Off. int. Epiz., 32 (1), 89-103. 
27. Nymo I., Tryland M. \& Godfroid J. (2011). - A review of Brucella infection in marine mammals, with special emphasis on Brucella pinnipedialis in the hooded seal (Cystophora cristata). Vet. Res., 42 (1), 93.

28. Hong P.C., Tsolis R.M. \& Ficht T.A. (2000). - Identification of genes required for chronic persistence of Brucella abortus in mice. Infect. Immun., 68 (7), 4102-4107.

29. Murphy E.A., Sathiyaseelan J., Parent M.A., Zou B.X. \& Baldwin C.L. (2001). - Interferon-gamma is crucial for surviving a Brucella abortus infection in both resistant C57BL/6 and susceptible BALB/c mice. Immunology, 103 (4), 511-518.

30. Skyberg J.A., Thornburg T., Rollins M., Huarte E., Jutila M.A. $\&$ Pascual D.W. (2011). - Murine and bovine gamma delta $\mathrm{T}$ cells enhance innate immunity against Brucella abortus infections. PLoS ONE, 6 (7), e21978.

31. Vitry M.A., De Trez C., Goriely S., Dumoutier L., Akira S., Ryffel B., Carlier Y., Letesson J.J. \& Muraille E. (2012). Crucial role of gamma interferon-producing CD4+ Thl cells but dispensable function of CD8+ T Cell, B Cell, Th2, and Th17 responses in the control of Brucella melitensis infection in mice. Infect. Immun., 80 (12), 4271-4280.

32. Barrionuevo P., Delpino M.V., Pozner R.G., Velásquez L.N., Cassataro J. \& Giambartolomei G.H. (2013). - Brucella abortus induces intracellular retention of MHC-I molecules in human macrophages down-modulating cytotoxic CD8(+) T cell responses. Cell. Microbiol., 15 (4), 487-502.

33. Sathiyaseelan J., Goenka R., Parent M., Benson R.M., Murphy E.A., Fernándes D.M., Foulkes A.S. \& Baldwin C.L. (2006). - Treatment of Brucella-susceptible mice with IL-12 increases primary and secondary immunity. Cell. Immunol., 243 (1), 1-9.

34. Pei J., Ding X., Fan Y., Rice-Ficht A. \& Ficht T.A. (2012). Toll-like receptors are critical for clearance of Brucella and play different roles in development of adaptive immunity following aerosol challenge in mice. Front. cell. infect. Microbiol., 2, 115.

35. Corsetti P.P., de Almeida L.A., Carvalho N.B., Azevedo V., Silva T.M., Teixeira H.C., Faria A.C. \& Oliveira S.C. (2013). - Lack of endogenous IL-10 enhances production of proinflammatory cytokines and leads to Brucella abortus clearance in mice. PLOS ONE, 8 (9), e74729.

36. Goenka R., Parent M.A., Elzer P.H. \& Baldwin C.L. (2011). - B cell-deficient mice display markedly enhanced resistance to the intracellular bacterium Brucella abortus. J. infect. Dis., 203 (8), 1136-1146.

37. Goenka R., Guirnalda P.D., Black S.J. \& Baldwin C.L. (2012). - B lymphocytes provide an infection niche for intracellular bacterium Brucella abortus. J. infect. Dis., 206 (1), 91-98.

38. Porte F., Liautard J.P. \& Kohler S. (1999). - Early acidification of phagosomes containing Brucella suis is essential for intracellular survival in murine macrophages. Infect. Immun., 67 (8), 4041-4047.
39. Boschiroli M.L., Ouahrani-Bettache S., Foulongne V., Michaux-Charachon S., Bourg G., Allardet-Servent A., Cazevieille C., Liautard J-.P., Ramuz M. \& O'Callaghan D. (2002). - The Brucella suis virB operon is induced intracellularly in macrophages. Proc. natl Acad. Sci. USA, 99 (3), 1544-1549.

40. Barquero-Calvo E., Martirosyan A., Ordoñez-Rueda D., Arce-Gorvel V., Alfaro-Alarcón A., Lepidi H., Malissen B., Malissen M., Gorvel J.P. \& Moreno E. (2013). - Neutrophils exert a suppressive effect on Th1 responses to intracellular pathogen Brucella abortus. PLoS Pathog., 9 (2), el 1003167.

41. Tomaso H., Kattar M., Eickhoff M., Wernery U., Al Dahouk S., Straube E., Neubauer H. \& Scholz H.C. (2010). - Comparison of commercial DNA preparation kits for the detection of brucellae in tissue using quantitative real-time PCR. BMC infect. Dis., 10, 100.

42. Weynants V., Godfroid J., Limbourg B., Saegerman C. \& Letesson J.J. (1995). - Specific bovine brucellosis diagnosis based on in vitro antigen-specific gamma interferon production. J. clin. Microbiol., 33 (3), 706-712.

43. Godfroid J., Nielsen K. \& Saegerman C. (2010). - Diagnosis of brucellosis in livestock and wildlife. Croatian med. J., 51 (4), 296-305.

44. Nielsen K., Gall D., Jolley M., Leishman G., Balsevicius S., Smith P., Nicoletti P. \& Thomas F. (1996). - A homogeneous fluorescence polarization assay for detection of antibody to Brucella abortus. J. immunol. Meth., 195 (1-2), 161-168.

45. Nielsen K., Smith P., Yu W., Elmgren C., Nicoletti P., Perez B., Bermudez R. \& Renteria T. (2007). - Second generation competitive enzyme immunoassay for detection of bovine antibody to Brucella abortus. Vet. Microbiol., 124 (1-2), 173-177.

46. McGiven J., Nicola A., Commander N., Duncombe L., Taylor A.V., Villari S., Dainty A., Thirlwall R., Bouzelmat N., Perrett L., Brew S. \& Stack J. (2012). - An evaluation of the capability of existing and novel serodiagnostic methods for porcine brucellosis to reduce false positive serological reactions. Vet. Microbiol., 160 (3-4), 378-386.

47. McGiven J.A. (2013). - New developments in the immunodiagnosis of brucellosis in livestock and wildlife. In Brucellosis: recent developments towards 'One Health' (G. Plumb, S. Olsen \& G. Pappas, eds). Rev. sci. tech. Off. int. Epiz., 32 (1), 163-176.

48. Weynants V., Tibor A., Denoel P.A., Saegerman C., Godfroid J., Thiange P. \& Letesson J.J. (1996). - Infection of cattle with Yersinia enterocolitica O:9 a cause of the false positive serological reactions in bovine brucellosis diagnostic tests. Vet. Microbiol., 48 (1-2), 101-112.

49. Bundle D.R., Cherwonogrodzky J.W., Gidney M.A.J., Meikle P.J., Perry M.B. \& Peters T. (1989). - Definition of Brucella-A and Brucella-M epitopes by monoclonal typing reagents and synthetic oligosaccharides. Infect. Immun., 57 (9), 2829-2836. 
50. Weynants V., Gilson D., Cloeckaert A., Tibor A., Denoel P.A., Godfroid F., Limet J.N. \& Letesson J.J. (1997). - Characterization of smooth lipopolysaccharides and O polysaccharides of Brucella species by competition binding assays with monoclonal antibodies. Infect. Immun., 65 (5), 1939-1943.

51. Kubler-Kielb J. \& Vinogradov E. (2013). - Reinvestigation of the structure of Brucella O-antigens. Carbohydr. Res., $378,144-147$.

52. Guiard J., Paszkiewicz E., Sadowska J. \& Bundle D.R. (2013). - Design and synthesis of a universal antigen to detect brucellosis. Angew. Chem. int. Ed. Engl., 52 (28), 7181-7185.

53. Moriyón I., Grilló M.J., Monreal D., González D., Marin C., López-Goni I., Mainar-Jaime R.C., Moreno E. \& Blasco J.M. (2004). - Rough vaccines in animal brucellosis: structural and genetic basis and present status. Vet. Res., 35 (1), 1-38.

54. Zaccheus M.V., Ali T., Cloeckaert A., Zygmunt M.S., Weintraub A., Iriarte M., Moriyón I. \& Widmalm G. (2013). - The epitopic and structural characterization of Brucella suis biovar 2 O-polysaccharide demonstrates the existence of a new M-negative C-negative smooth Brucella serovar. PLOS ONE, 8 (1), e53941.

55. Fretin D., Mori M., Czaplicki G., Quinet C., Maquet B., Godfroid J. \& Saegerman C. (2013). - Unexpected Brucella suis biovar 2 infection in a dairy cow, Belgium. Emerg. infect. Dis., 19 (12), 2053-2054.

56. Godfroid J., Scholz H.C., Barbier T., Nicolas C., Wattiau P., Fretin D., Whatmore A.M., Cloeckaert A., BlascoJ.M., Moriyón I., Saegerman C., Muma J.B., Al Dahouk S., Neubauer H. \& Letesson J.J. (2011). - Brucellosis at the animal/ecosystem/human interface at the beginning of the 21 st century. Prev. vet. Med., 102 (2), 118-131.

57. Bengis R.G., Kock R.A. \& Fischer J. (2002). - Infectious animal diseases: the wildlife/livestock interface. In Infectious diseases of wildlife: detection, diagnosis and management (Part One) (R.G. Bengis, ed.). Rev. sci. tech. Off. int. Epiz., 21 (1), 53-65.

58. Rhyan J.C., Gidlewski T., Roffe T.J., Aune K., Philo L.M. \& Ewalt D.R. (2001). - Pathology of brucellosis in bison from Yellowstone National Park. J. Wildl. Dis., 37 (1), 101-109.

59. Olsen S. \& Johnson C. (2012). - Immune responses and safety after dart or booster vaccination of bison with Brucella abortus strain RB51. Clin. vaccine Immunol., 19 (5), 642-648.

60. Cheville N.F., Olsen S.C., Jensen A.E., Stevens M.G., Palmer M.V. \& Florance A.M. (1996). - Effects of age at vaccination on efficacy of Brucella abortus strain RB51 to protect cattle against brucellosis. Am. J. vet. Res., 57 (8), 1153-1156.

61. Roffe T.J., Olsen S.C., Gidlewski T., Jensen A.E., Palmer M.V. \& Huber R. (1999). - Biosafety of parenteral Brucella abortus RB51 vaccine in bison calves. J. Wildl. Manag., 63 (3), 950-955.
62. Olsen S., Fach S., Palmer M.V., Sacco R., Stoffregen W. \& Waters W. (2006). - Immune responses of elk to initial and booster vaccinations with Brucella abortus strain RB51 or 19. Clin. vaccine Immunol., 13 (10), 1098-1103.

63. Kreeger T.J., Cook W.E., Edwards W.H., Elzer P.H. \& Olsen S.C. (2002). - Brucella abortus strain RB51 vaccination in elk II. Failure of high dosage to prevent abortion. J. Wildl. Dis., 38 (1), 27-31.

64. Roffe T.J., Jones L.C., Coffin K., Drew M.L., Sweeney S.J., Hagius S.D., Elzer P.H. \& Davis D. (2004). - Efficacy of single calfhood vaccination of elk with Brucella abortus strain 19. J. Wildl. Manag., 68 (4), 830-836.

65. Castrodale L. (2011). - Human and animal brucellosis in Alaska. Alaska Epidem. Bull., 31 (28 December). Available at: www.epi.alaska.gov/bulletins/docs/b2011_31.pdf (accessed on 10 June 2014).

66. University of Alaska Fairbanks (2012). - Reindeer Research Program. The Seward Peninsula. Available at: www.reindeer. salrm.uaf.edu/about_reindeer/seward_pennisula.php (accessed on 10 June 2014).

67. Lambourn D., Garner M., Ewalt D., Raverty S., Sidor I., Jeffries S.J., Rhyan J. \& Gaydos J.K. (2013). - Brucella pinnipedialis infections in Pacific harbor seals (Phoca vitulina richardsi) from Washington State, USA. J. Wildl. Dis., 49 (4), 802-815.

68. Scholz H.C., Hubalek Z., Nesvadbova J., Tomaso H., Vergnaud G., Le Fleche P., Whatmore A.M., Al Dahouk S., Kruger M., Lodri C. \& Pfeffer M. (2008). - Isolation of Brucella microti from soil. Emerg. infect. Dis., 14 (8), 1316-1317.

69. Al Dahouk S., Hofer E., Tomaso H., Vergnaud G., Le Fleche P., Cloeckaert A., Koylass M.S., Whatmore A.M., Noeckler K. \& Scholz H.C. (2012). - Intraspecies biodiversity of the genetically homologous species Brucella microti. Appl. environ. Microbiol., 78 (5), 1534-1543.

70. Tiller R.V., Gee J.E., Frace M.A., Taylor T.K., Setubal J.C., Hoffmaster A.R. \& De B.K. (2010). - Characterization of novel Brucella strains originating from wild native rodent species in North Queensland, Australia. Appl. environ. Microbiol., 76 (17), 5837-5845

71. Eisenberg T., Hamann H.P., Kaim U., Schlez K., Seeger H., Schauerte N., Melzer F., Tomaso H., Scholz H.C., Koylass M.S., Whatmore A.M. \& Zschöck M. (2012). Isolation of potentially novel Brucella spp. from frogs. Appl. environ. Microbiol., 78 (10), 3753-3755.

72. Nielsen K. (2002). - Diagnosis of brucellosis by serology. Vet. Microbiol., 90 (1-4), 447-459.

73. Pedersen K., Quance C.R., Robbe-Austerman S., Piaggio A.J., Bevins S.N., Goldstein S.M., Gaston W.D. \& DeLiberto T.J. (2014). - Identification of Brucella suis from feral swine in selected states in the USA. J. Wildl. Dis., 50 (2),171-179. doi: 10.7589/2013-09-235. 
74. Verger J.M., Garin-Bastuji B., Grayon M. \& Mahe A.M. (1989). - Brucella melitensis infection in cattle in France. Ann. Rech. vét., 20 (1), 93-102.

75. Álvarez J., Sáez J.L., García N., Serrat C., Pérez-Sancho M., González S., Ortega M.J., Gou J., Carbajo L., Garrido F., Goyache J. \& Domínguez L. (2011). - Management of an outbreak of brucellosis due to B. melitensis in dairy cattle in Spain. Res. vet. Sci., 90 (2), 208-211.

76. Holt H.R., Eltholth M.M., Hegazy Y.M., El-Tras W.F., Tayel A.A. \& Guitian J. (2011). - Brucella spp. infection in large ruminants in an endemic area of Egypt: cross-sectional study investigating seroprevalence, risk factors and livestock owner's knowledge, attitudes and practices (KAPs). BMC public Hlth, 11 (341). doi:10.1186/1471-2458-11-341.

77. Menshawy A.M., Pérez-Sancho M., García-Seco T., Hosein H.I., García N., Martínez I., Sayour A.E., Goyache J., Azzam R.A., Domínguez L. \& Álvarez J. (2014). - Assessment of genetic diversity of zoonotic Brucella spp. recovered from livestock in Egypt using multiple locus VNTR analysis. Biomed. Res. int., E-pub.: 6 January. doi:10.1155/2014/353876.

78. Lucero N.E., Ayala S.M., Escobar G.I. \& Jacob N.R. (2008). Brucella isolated in humans and animals in Latin America from 1968 to 2006. Epidemiol. Infect., 136 (4), 496-503.

79. Xin X. (1986). - Orally administrable brucellosis vaccine: Brucella suis strain 2 vaccine. Vaccine, 4 (4), 212-216.

80. Jiang H., Du P., Zhang W., Wang H., Zhao H., Piao D., Tian G., Chen C. \& Cui B. (2013). - Comparative genomic analysis of Brucella melitensis vaccine strain M5 provides insights into virulence attenuation. PLoS ONE, 8 (8), e70852.

81. Gresham C.S., Gresham C.A., Duffy M.J., Faulkner C.T. \& Patton S. (2002). - Increased prevalence of Brucella suis and pseudorabies virus antibodies in adults of an isolated feral swine population in coastal South Carolina. J. Wildl. Dis., 38 (3), 653-656.

82. Carrington M., Choe U., Ubillos S., Stanek D., Campbell M., Wansbrough L., Lee P., Churchwell G., Rosas K., Zaki S., Drew C., Paddock C., DeLeon-Carnes M., Guerra M., Hoffmaster A., Tiller R.V. \& De B. (2012). - Fatal case of brucellosis misdiagnosed in early stages of Brucella suis infection in a 46-year-old patient with Marfan syndrome. J. clin. Microbiol., 50 (6), 2173-2175.

83. Ocholi R.A., Kwaga J.K.P., Ajogi I. \& Bale J.O.O. (2004). Phenotypic characterization of Brucella strains isolated from livestock in Nigeria. Vet. Microbiol., 103 (1-2), 47-53.

84. Samaha H., Al-Rowaily M., Khoudair R.M. \& Ashour H.M. (2008). - Multicenter study of brucellosis in Egypt. Emerg. infect. Dis., 14 (12), 1916-1918.

85. Matope G., Bhebhe E., Muma J., Skjerve E. \& Djonne B. (2009). - Characterization of some Brucella species from Zimbabwe by biochemical profiling and AMOS-PCR. BMC Res. Notes, 2 (1), 261.
86. Muendo E., Mbatha P., Macharia J., Abdoel T., Janszen P., Pastoor R. \& Smits H. (2012). - Infection of cattle in Kenya with Brucella abortus biovar 3 and Brucella melitensis biovar 1 genotypes. Trop. anim. Hlth Prod., 44 (1), 17-20.

87. Gwida M., El-Gohary A., Melzer F., Khan I., Rösler U. \& Neubauer H. (2012). - Brucellosis in camels. Res. vet. Sci., 92 (3), 351-355.

88. Musa M.T., Eisa M.Z.M., El Sanousi E.M., Wahab M.B.A. \& Perrett L. (2008). - Brucellosis in camels (Camelus dromedarius) in Darfur, Western Sudan. J. comp. Pathol., 138 (2-3), 151155.

89. Nymo I.H., Tryland M., Frie A.K.H., Haug T., Foster G., Rødven R. \& Godfroid J. (2013). - Age-dependent prevalence of anti-Brucella antibodies in hooded seals Cystophora cristata. Dis. aquat. Organisms, 106 (3), 187-196.

90. Whatmore A.M., Dawson C.E., Groussaud P., Koylass M.S., King A.C., Shankster S.J., Sohn A.H., Probert W.S. \& McDonald W.L. (2008). - Marine mammal Brucella genotype associated with zoonotic infection. Emerg. infect. Dis., 14 (3), 517-518.

91. Audic S., Lescot M., Claverie J.M., Cloeckaert A. \& Zygmunt M.S. (2011). - The genome sequence of Brucella pinnipedialis B2/94 sheds light on the evolutionary history of the genus Brucella. BMC evol. Biol., 11 (200). doi:10.1186/ 1471-2148-11-200.

92. Bohlin J., Snipen L., Cloeckaert A., Lagesen K., Ussery D., Kristoffersen A.B. \& Godfroid J. (2010). - Genomic comparisons of Brucella spp. and closely related bacteria using base compositional and proteome based methods. BMC evol. Biol., 10 (249). doi:10.1186/1471-2148-10-249.

93. Crump J.A., Morrissey A.B., Nicholson W.L., Massung R.F., Stoddard R.A., Galloway R.L., Ooi E.E., Maro V.P., Saganda W., Kinabo G.D., Muiruri C. \& Bartlett J.A. (2013). - Etiology of severe non-malaria febrile illness in northern Tanzania: a prospective cohort study. PLoS negl. trop. Dis., 7 (7), e2324. doi:10.1371/journal.pntd.0002324.s001.

94. Jelastopulu E., Bikas C., Petropoulos C. \& Leotsinidis M. (2008). - Incidence of human brucellosis in a rural area in Western Greece after the implementation of a vaccination programme against animal brucellosis. BMC public Hlth, 8 (241). doi:10.1186/1471-2458-8-241.

95. Lee H.S., Her M., Levine M. \& Moore G.E. (2013). - Time series analysis of human and bovine brucellosis in South Korea from 2005 to 2010. Prev. vet. Med., 110 (2), 190-197.

96. Atluri V.L., Xavier M.N., de Jong M.F., den Hartigh A.B. \& Tsolis R.M. (2011). - Interactions of the human pathogenic Brucella species with their hosts. Annu. Rev. Microbiol., 65, 523-541.

97. Sprague L.D., Al-Dahouk S. \& Neubauer H. (2012). - A review on camel brucellosis: a zoonosis sustained by ignorance and indifference. Pathog. global Hlth, 106 (3), 144-149. 
98. El-Tras W.F., Tayel A.A., Eltholth M.M. \& Guitian J. (2010). - Brucella infection in fresh water fish: evidence for natural infection of Nile catfish, Clarias gariepinus, with Brucella melitensis. Vet. Microbiol., 141 (3-4), 321-325.

99. Dokuzoguz B., Ergonul O., Baykam N., Esener H., Kilic S., Celikbas A., Eren S. \& Esen B. (2005). - Characteristics of B. melitensis versus B. abortus bacteraemias. J. Infection, 50 (1), 41-45.

100. Brew S.D., Perrett L.L., Stack J.A., MacMillan A.P. \& Staunton N.J. (1999). - Human exposure to Brucella recovered from a sea mammal. Vet. Rec., 144 (17), 483.

101. Sohn A.H., Probert W.S., Glaser C.A., Gupta N., Bollen A.W., Wong J.D., Grace E.M. \& McDonald W.C. (2003). - Human neurobrucellosis with intracerebral granuloma caused by a marine mammal Brucella spp. Emerg. infect. Dis., 9 (4), 485-488.

102. McDonald W.L., Jamaludin R., Mackereth G., Hansen M., Humphrey S., Short P., Taylor T., Swingler J., Dawson C.E., Whatmore A.M., Stubberfield E., Perrett L.L. \& Simmons G. (2006). - Characterization of a Brucella sp. strain as a marine-mammal type despite isolation from a patient with spinal osteomyelitis in New Zealand. J. clin. Microbiol., 44 (12), 4363-4370.

103. Roth F,, Zinsstag J., Orkhon D., Chimed-Ochir G., Hutton G., Cosivi O., Carrin G. \& Otte J. (2003). - Human health benefits from livestock vaccination for brucellosis: case study. Bull. WHO, 81 (12), 867-876.

104. Pappas G., Papadimitriou P., Akritidis N., Christou L. \& Tsianos E.V. (2006). - The new global map of human brucellosis. Lancet infect. Dis., 6 (2), 91-99.

105. Li Y.J., Li X.L., Liang S., Fang L.Q. \& Cao W.C. (2013). Epidemiological features and risk factors associated with the spatial and temporal distribution of human brucellosis in China. BMC infect. Dis., 13, 547. doi:10.1186/1471-233413-547.

106. Letesson J.J., Tibor A., van Eynde G., Wansard V., Weynants V., Denoel P. \& Saman E. (1997). - Humoral immune responses of Brucella-infected cattle, sheep, and goats to eight purified recombinant Brucella proteins in an indirect enzyme-linked immunosorbent assay. Clin. diagn. Lab. Immunol., 4 (5), 556-564.

107. Escobar G.I., Jacob N.R., López G., Ayala S.M., Whatmore A.M. \& Lucero N.E. (2013). - Human brucellosis at a pig slaughterhouse. Comp. Immunol. Microbiol. infect. Dis., 36 (6), 575-580.
108. Deqiu S., Donglou X. \& Jiming Y. (2002). - Epidemiology and control of brucellosis in China. Vet. Microbiol., 90 (1-4), $165-182$.

109. Chen J.D., Ke C.W., Deng X., Jiang S., Liang W., Ke B.X., Li B., Tan H. \& Liu M. (2013). - Brucellosis in Guangdong Province, People's Republic of China, 2005-2010. Emerg. infect. Dis., 19 (5), 817-818.

110. Mick V., Le Carrou G., Corde Y., Game Y., Jay M. \& Garin-Bastuji B. (2014). - Brucella melitensis in France: persistence in wildlife and probable spillover from Alpine ibex to domestic animals. PLoS ONE, 9 (4), e94168. doi: 10.1371/journal.pone.0094168.

111. Kin M.S., Fort M., de Echaide S.T. \& Casanave E.B. (2014). - Brucella suis in armadillos (Chaetophractus villosus) from La Pampa, Argentina. Vet. Microbiol., 170 (3-4), 442-445.

112. Marcotty T., Matthys F., Godfroid J., Rigouts L., Ameni G., van Pittius N.G., Kazwala R., Muma J., van Helden P., Walravens K., de Klerk L.M., Geoghegan C., Mbotha D., Otte M., Amenu K., Abu Samra N., Botha C., Ekron M., Jenkins A., Jori F., Kriek N., McCrindle C., Michel A., Morar D., Roger F., Thys E. \& van den Bossche P. (2009). - Zoonotic tuberculosis and brucellosis in Africa: neglected zoonoses or minor public-health issues? The outcomes of a multi-disciplinary workshop. Ann. trop. Med. Parasitol., 103 (5), 401-411.

113. Van Den Wijngaard C., Dijkstra F, Van Pelt W., Van Asten L., Kretzschmar M., Schimmer B., Nagelkerke N., Vellema P., Donker G. \& Koopmans M. (2011). - In search of hidden Q-fever outbreaks: linking syndromic hospital clusters to infected goat farms. Epidemiol. Infect., 139 (1), 19-26.

114. Zinsstag J., Roth F., Orkhon D., Chimed-Ochir G., Nansalmaa M., Kolar J. \& Vounatsou P. (2005). - A model of animal-human brucellosis transmission in Mongolia. Prev. vet. Med., 69 (1-2), 77-95. 